\title{
The potential of using low oxygen and ethyl formate or ethyl acetate to disinfest fresh fruit in storage
}

\author{
L.E. Jamieson, N.E.M. Page-Weir, A. Chhagan, P.G. Connolly, J. Poulton \\ and A.M. Kean \\ The New Zealand Institute for Plant E Food Research Limited (Plant E Food Research), \\ Private Bag 92169, Auckland \\ Corresponding author: Lisa.Jamieson@plantandfood.co.nz
}

\begin{abstract}
Low oxygen and/or 'generally recognised as safe' (GRAS)/food additive (FA) treatments in combination with cool storage have the potential to disinfest a range of commodities of various pests. This paper reports on research to determine the tolerance of second/third and fifth instar codling moth larvae, fifth instar lightbrown apple moth larvae, mixed stages of greedy scale and obscure mealybugs, and diapausing two-spotted mite adults to ultra low oxygen (ULO, $<0.5 \% \mathrm{O}_{2}$ ) and ULO combined with two GRAS/ FA compounds, ethyl acetate and ethyl formate. ULO alone did not consistently enhance mortality of these pests compared with air cool storage. However, addition of 3000-5000 ppm of ethyl acetate or ethyl formate reduced the time taken to achieve $99 \%$ mortality from weeks or months to between $8 \mathrm{~h}$ and 5 days, depending on the pest.
\end{abstract}

Keywords coolstorage, GRAS, ULO, codling moth, lightbrown apple moth, mealybug, scale, two-spotted mite, ethyl acetate, ethyl formate.

\section{INTRODUCTION}

Mealybugs, mites, scale insects and lepidopteran pests are major market access issues for New Zealand apples and other fresh commodities. The main quarantine and pre-shipment (QPS) treatment used on fresh produce has been fumigation with methyl bromide (MeBr). However, because of MeBr's undesirable traits, including high toxicity to humans, ozonedepleting potential, adverse effects on some commodities and slow desorption from some commodities, replacements are being sought.

With the advent of the HarvestWatch ${ }^{\mathrm{TM}}$ system, in which chlorophyll fluorescence sensors are used to monitor the low $\mathrm{O}_{2}$ stress point for a batch of fruit, dynamic controlled atmosphere (DCA) storage became possible in situations where ultra low oxygen (ULO) concentrations in the range $0.2 \%$ to $0.8 \%$ can be used in storage to enhance fruit quality (Prange et al. 2002; Lallu et al. 2009, 2010). These ULO concentrations have the potential to enhance the mortality of unwanted pests on fruit in storage (Lay-Yee \& Whiting 1996; Whiting et al. 1991, 1992, 1995; Whiting \& Hoy 1997).

There is also potential to use "Generally Recognised As Safe" (GRAS) and Food Additive (FA) compounds, which have pesticidal activity (Bradfield et al. 2002, 2003), to disinfest fruit at low temperature. A GRAS/FA compound is considered safe for use with human food 
(Anonymous 1993) and GRAS/FA status for a compound is determined by the United States Food and Drug Administration (US FDA). The US FDA GRAS substances database currently lists 373 substances (US FDA 2006) and the 'Everything added to Food in the United States' (EAFUS) database lists more than 3000 substances (US FDA 2011). The advantage of treatments utilising GRAS/FA compounds to control pests is that they are already accepted by the United States Congress after a series of strict criteria has been satisfied. GRAS/FA substances may therefore be excluded from mandatory premarket approval by the US FDA (Hallagan \& Hall 1995) when used on produce to control pests and may also be exempt from Maximum Residue Limits (MRL) for use as a postharvest treatment on plant products.

Five years of GRAS compound research was conducted at HortResearch (now Plant \& Food Research) in the early 2000s, in which about 25 GRAS/FA volatiles were screened for their efficacy against lightbrown apple moth (Bradfield et al. 2002, 2003; P.R. Dentener \& L.E. Jamieson, Plant \& Food Research, unpublished data). In general, shorter-chained compounds tended to be more effective. Formates resulted in higher mortality than acetates and terpenes, and some isomers were more effective than their straight chains. Many of these GRAS/FA compounds have explosive limits between 1.7 and $3.3 \%$, but using them with low oxygen and below these limits would ensure safe application.

Ethyl formate (EF) is a GRAS/FA plant volatile compound that breaks down into formic acid and ethanol. Ethyl formate in combination with carbon dioxide is available in New Zealand under the trade name VAPORMATE ${ }^{\mathrm{TM}}$ (16.7 wt $\%$ ethyl formate dissolved in liquid $\mathrm{CO}_{2}$ ). Ethyl formate is effective against a range of pests on a range of commodities (Krishna et al. 2002; Simpson et al. 2004; De Lima 2006; Simpson et al. 2007; van Epenhuijsen et al. 2007; Damcevski et al. 2010; Finkelman et al. 2010). Ethyl acetate (EA) is another GRAS/FA compound with pesticidal activity (van Epenhuijsen et al. 2007) and is well known as an insecticide by insect collectors.
There is potential to develop safe ULO + GRAS/ FA compound disinfestation treatments for fresh produce during the initial stages of cool storage. This paper reports on a study that investigated the efficacy of ULO and/or ULO combined with ethyl formate or ethyl acetate against a range of pests.

\section{METHODS}

These trials were undertaken at Plant \& Food Research (PFR), Mt Albert, Auckland, between September 2010 and May 2011.

\section{Pest supply and establishment}

Codling moth (Cydia pomonella) larvae at second/ third instar stage were obtained from a colony reared on modified (A.M. Barrington, Plant \& Food Research, personal communication) Brinton's artificial diet (Brinton et al. 1969) in individual tubes at the PFR insect-rearing facility using 16:8 h light:dark (L:D), a temperature of $25^{\circ} \mathrm{C}$ and $60 \% \mathrm{RH}$. Three to five second/ third instar larvae were placed in a cage $(2.8 \mathrm{~cm}$ diameter, $1 \mathrm{~cm}$ high, with the top covered in fine mesh gauze), which was adhered over the calyx of an apple using BluTack ${ }^{\circledR}$. Five apples were placed on a cardboard fibre apple tray ('Friday tray'), which had been cut into a circle approximately $25 \mathrm{~cm}$ in diameter. The tray and apples were enclosed within a fine mesh bag secured with a twist tie and placed at $20^{\circ} \mathrm{C}$ for 3-4 days to enable larvae to burrow in to the apples before treatment.

Fifth instar codling moth larvae programmed for diapause were reared on modified Brinton's diet for 20 days at $25^{\circ} \mathrm{C}, 12: 12 \mathrm{~h} \mathrm{~L}: \mathrm{D}$. Between 30 and 35 such larvae were placed in tissue paper to cocoon for 3-4 days before being placed in the fine mesh bag around the five apples infested with second/third instar codling moth larvae for treatment. Three replicate mesh bags, each containing 30-35 cocooning fifth instar codling moth larvae and the five apples infested with second/third instar codling moth larvae, were set up for each treatment.

Fifth instar lightbrown apple moth (LBAM, Epiphyas postvittana) larvae were mass reared 
on modified (A.M. Barrington, Plant \& Food Research, personal communication) general purpose diet (Clare et al. 1987) at $20^{\circ} \mathrm{C}, 16: 8 \mathrm{~h}$ L:D. The day before treatment, between 30 and 35 such larvae were placed on five apples on a cut-out circular 'Friday tray' and stored at $20^{\circ} \mathrm{C}$. Three replicate trays, each containing five LBAMinfested apples, were set up for each treatment.

Two-spotted mites (TSM, Tetranychus urticae) were collected from orchard sites at Clyde, Central Otago, and a colony was established at PFR Auckland on bean plants, based on methods developed by Singh \& Clare (1993). A portion of the colony was exposed to diapausing conditions (12:12 $\mathrm{h} \mathrm{L}: \mathrm{D}$ at $\left.15^{\circ} \mathrm{C}\right)$ during development to induce the adults to move to a black cardboard shelter $(5 \mathrm{~cm} \times 6 \mathrm{~cm})$ and enter a diapausing life stage. Cards of diapausing TSMs were collected and kept at $4^{\circ} \mathrm{C}$ until required. Cards with approximately 100-200 diapausing mites were placed into plastic containers with gauze at either end for treatment. Three replicate cards, each containing 100-200 diapausing TSM, were set up for each treatment.

Greedy scale insects (Hemiberlesia rapax) were reared on squash and red-skinned potatoes at 20$23^{\circ} \mathrm{C}, 16: 8 \mathrm{~h} \mathrm{~L}: \mathrm{D}$ at PFR Auckland. Potatoes infested with $>50$ greedy scale insects of each life stage were placed in a plastic container with gauze at either end and treated. Three replicate containers, each containing 1-3 greedy scale-infested potatoes, were set up for each treatment.

Obscure mealybugs (Pseudococcus viburni) were reared on sprouting red-skinned potatoes at $20^{\circ} \mathrm{C}, 16: 8 \mathrm{~h} \mathrm{~L}: \mathrm{D}$ at PFR Auckland. Parts of the potato with ca 30-50 mealybugs were excised with a scalpel and pinned on to the calyx end of 2-5 apples, placed on 'Friday trays', enclosed with insect-proof terylene mesh bags and left for 3 days at $20^{\circ} \mathrm{C}$ for the mealybugs to move on to the apples. Three replicate trays, each containing 2-5 mealybug-infested apples, were set up for each treatment.

\section{Treatment apparatus}

Trials were conducted using a 20-litre bucket flow-through system attached to a ULO $\left(0.4 \% \mathrm{O}_{2}\right.$,
99.6\% $\mathrm{N}_{2}$ ) supply or air supply at a flow rate of one complete atmosphere change per hour. Trays of codling moth- and mealybug-infested apples and containers with TSM on cards and potatoes infested with scale were loaded onto stands within 20-litre buckets and sealed. Three replicate buckets were set up for each treatment, with the whole system being kept at $0.5^{\circ} \mathrm{C}$. Each bucket had an inlet and an outlet line to a central manifold where the flow rate could be regulated. For ULO + GRAS/FA treatments, the primary ULO line was bubbled through a jar containing either $500 \mathrm{ml}$ ethyl acetate or ethyl formate, generating either 29,000 ppm ethyl acetate or 93,000 ppm ethyl formate in the headspace above. The ethyl acetate and ethyl formate reservoirs were topped up daily. The gas line from the headspace above the ethyl acetate and ethyl formate reservoirs was further diluted with a secondary ULO flow by either 2.9 times or 9.3 times, respectively, and this ethyl acetate or ethyl formate-enriched atmosphere was then passed through a second empty jar to drop out any moisture. The concentration of ethyl acetate and ethyl formate in the supply line after dilution was 2,871-5,661 ppm and 3,069-4,247 ppm, respectively.

One-millilitre samples of the atmosphere in each bucket were taken and the amounts of EF, EA and $\mathrm{O}_{2}$ were measured using a Philips ${ }^{\circledR}$ PYE UNICAM PU4500 Chromatograph and an $\mathrm{O}_{2}$ analyser with Hewlett Packard ${ }^{\circledR} \mathrm{HO} 3395$ integrator respectively. It took $4-5 \mathrm{~h}$ to reach $<1 \% \mathrm{O}_{2}$ and after this, $\mathrm{O}_{2}$ concentrations in the buckets were $0.72 \pm 0.05 \%$. After equilibrium, amounts of ethyl acetate and ethyl formate in buckets were 1,689-3,505 ppm and 2,628-3,550 ppm, respectively.

Infested samples were removed at various time intervals to achieve mortalities between 50\% and $100 \%$ to enable lethal times for $99 \%$ mortality to be calculated.

\section{Pest assessment after treatment}

After treatment, pests were transferred to a $20^{\circ} \mathrm{C}$ room for 2-4 days before assessment. Codling moth larvae, lightbrown apple moth larvae, longtailed mealybugs, TSMs and greedy scale crawlers were assessed as live (movement) or dead 
(no movement) when gently prodded with a pin or forceps. Codling moth-infested apples were carefully cut open and any second/third instar larvae assessed. Fifth instar codling moth larvae were removed from the tissue paper, cocoons were opened and assessed. Lightbrown apple moth fifth instar larvae were recovered from around apples, on the tray and inside the bag and assessed. Obscure mealybugs on apples, remaining on the potato and inside the bag were assessed. The viability of the non-mobile greedy scale insect life stages on potatoes was recorded as live or dead according to physical characters. The scale insect caps were removed and the scale insects were recorded as alive if they were yellow and turgid (fluid-filled). When scale insects were a dull yellow and/or slightly flaccid to touch, the bodies were gently pulled with a fine pair of forceps and if the stylet withdrew easily or was already withdrawn, the insect was recorded as dead. If the stylet was less easily withdrawn, the insects were recorded as alive. Scale insects that were brown or flaccid or dried up were recorded as dead.

\section{Statistical analysis}

For mortality response figures (Figures 1-6), the loess smoothing function (Chambers \& Hastie 1992) was used in R ( R Development Core Team 2012) to draw a smooth line through the mean mortality points for each pest after exposure to different GRAS and ULO treatments at each exposure time. An angular transformation $(\arcsin (\operatorname{sqrt}(\mathrm{p})))$ was applied to the percentage (p) to stabilize the variance (i.e. so that the error bar was appropriate over the entire range of $1-100 \%)$. Standard errors for each treatment were calculated at every treatment time. The root mean square of these SEMs gave a mean SEM for each life stage exposed to each treatment. In Figures 1-6 percent mortality is presented on an angular scale and treatment time is presented on a modified log scale to display both GRAS and ULO/air mortality results.

Time mortality data for each replicate were fitted using generalised linear model (Chambers \& Hastie 1992) with the complementary loglog (clog-log) link (Preisler \& Robertson 1989), with time as the explanatory variable to derive estimated lethal times (days) to achieve 99\% mortality $\left(\mathrm{LT}_{99}\right)$. These estimates were calculated as the time to achieve a mortality of $c+(1-c) \times m$, where $c$ was the control mortality and $m$ the estimated proportion mortality. For each life stage, a geometric mean LT and its associated standard error (SEM) were estimated, from which a 95\% confidence interval (CI) was calculated. Non-overlap of the $95 \%$ CIs is approximately equal to a test for difference at $\mathrm{P}=0.01$.

\section{RESULTS}

Diapausing TSM and fifth instar codling moth larvae were the most tolerant pests of those tested to air and ULO cool storage at $0.5^{\circ} \mathrm{C}$ (Figures 1 \& 2). ULO tended to enhance mortality of fifth instar codling larvae programmed for diapause at $0.5^{\circ} \mathrm{C}$ but only after 115 days of storage, well beyond the useful time for a disinfestation treatment particularly for early season fruit (Figure 2). ULO had no additional impact on the mortality of diapausing TSM (Figure 1). Lethal times for $99 \%$ mortality of diapausing fifth instar codling moth larvae and TSM adults were reduced from hundreds of days in air and ULO cool storage to 1.4-2.3 days or 0.2-0.5 days when ethyl acetate or ethyl formate, respectively, were added to ULO (Table 1).

Complete kill of second/third instar codling moth larvae was achieved at 49 days of storage at $0.5^{\circ} \mathrm{C}$ in air or ULO (Figure 3). ULO alone did not significantly reduce the estimated time for $99 \%$ mortality of second/third instar codling moth larvae (39.2 days) compared with air (42.6 days) (Table 1). However, the addition of ethyl acetate or ethyl formate to ULO reduced the lethal time for $99 \%$ mortality to 5.7 days. Second/third instar codling moth larvae were the most tolerant pest/life stage to EF/ULO or EA/ ULO treatment at $0.5^{\circ} \mathrm{C}$, probably because they were mostly found inside the fruit where the ethyl acetate and ethyl formate may not have reached lethal concentrations.

ULO did not significantly enhance the mortality of fifth instar LBAM larvae, mixed life stages of obscure mealybug or greedy scale insects at $0.5^{\circ} \mathrm{C}$ compared with air storage (Figures 4 to 6). Adding 


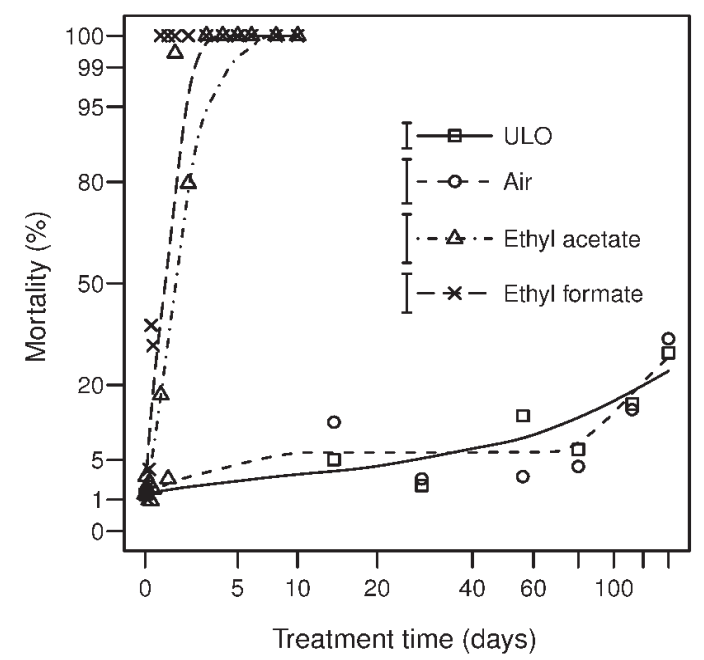

Figure 1 Fitted mortality lines for diapausing two-spotted mite adults during ultra low oxygen (ULO), air, or ULO with either ethyl acetate or ethyl formate applied in cool storage at $0.5^{\circ} \mathrm{C}$. The air treatment is included as a control. $\mathrm{n}=$ 128-966 for each sample point.

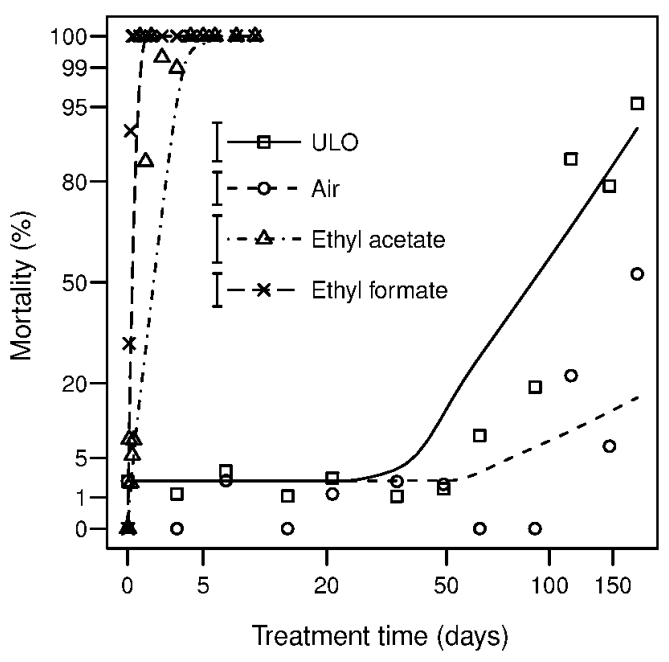

Figure 2 Fitted mortality lines for fifth instar codling moth larvae (programmed for diapause) during ultra low oxygen (ULO), air, or ULO with either ethyl acetate or ethyl formate applied in cool storage at $0.5^{\circ} \mathrm{C}$. The air treatment is included as a control. $\mathrm{n}=78-327$ for each sample point.

Table 1 Estimated lethal time (days) for $99 \%$ mortality $\left(\mathrm{LT}_{99}\right)(95 \%$ confidence limits) of second/third instar codling moth $\left(\mathrm{CM} 2^{\star}\right)$, fifth instar codling moth larvae programmed for diapause (CM $\left.5^{\star} \mathrm{D}\right)$, fifth instar lightbrown apple moth larvae (LBAM $5^{\star}$ ), diapausing adult two-spotted mites (TSM D), mixed life stages of obscure mealybug (OMB) and mixed life stages of greedy scale (GS) exposed to air cool storage (Air), ultra low oxygen (ULO), ULO with ethyl acetate or ULO with ethyl formate at $0.5^{\circ} \mathrm{C}$.

\begin{tabular}{lcccc}
\hline $\begin{array}{l}\text { Pest/life } \\
\text { stage }\end{array}$ & Air & ULO & $\begin{array}{c}\text { ULO+Ethyl } \\
\text { acetate }\end{array}$ & $\begin{array}{c}\text { ULO+Ethyl } \\
\text { formate }\end{array}$ \\
\hline TSM D & $505.0(275.5-925.9)^{1}$ & $331.3(169.8-570.8)^{1}$ & $2.3(1.2-4.2)$ & $0.5(0.3-0.9)$ \\
CM 5 $^{\star} \mathrm{D}$ & $246.0(171.7-352.4)^{1}$ & $175.5(122.5-251.4)$ & $1.4(1.0-2.0)$ & $0.2(0.1-0.3)$ \\
CM 2 $^{*}$ & $42.6(29.7-61.0)$ & $39.2(27.4-61.0)$ & $5.7(3.9-8.1)$ & $5.7(3.9-8.1)$ \\
LBAM 5 $^{*}$ & $42.6(29.7-61.0)$ & $36.3(23.6-56.1)$ & $0.5(0.3-0.7)$ & $0.1(0.1-0.2)$ \\
OBM & $34.7(16.7-72.1)$ & $49.1(23.6-101.9)$ & $0.5(0.2-1.1)$ & $0.2(0.1-0.4)$ \\
GS & $6.8(4.9-9.4)$ & 11.4 & 0.1 & -2 \\
\hline
\end{tabular}

${ }^{1} \mathrm{LT}_{99}$ estimates are unreliable, as the mean mortality only reached $52.7 \%$ at 175 days for fifth instar codling moth larvae exposed to air cool storage, and $29.5 \%$ or $33.9 \%$ at 140 days for diapausing adult two-spotted mites exposed to air and ULO and cool storage, respectively.

${ }^{2} \mathrm{LT}_{99}$ estimates could not be estimated as there were not enough mortality points smaller than $100 \%$. 
ethyl formate or ethyl acetate to ULO reduced the lethal times for $99 \%$ mortality of these surface pests from 6.8-49.1 days down to $0.1-0.5$ days (Table 1 ).

In general, the efficacy of ethyl formate against pests tended to be higher during the initial stages than that of ethyl acetate (Figures 1-4).

\section{DISCUSSION}

ULO at $0.5^{\circ} \mathrm{C}$ compared with air did not generally enhance mortality of the pests tested in this study. However, addition of ca 3000-5000 ppm of ethyl acetate or ethyl formate to the ULO gas line reduced the time taken to achieve 99\% mortality from weeks or months to between 8 $\mathrm{h}$ and 5 days, depending on the pest. In general, ethyl formate was faster at achieving a higher percentage mortality than ethyl acetate.

The order of tolerance of species tested in this study to ethyl formate or ethyl acetate treatment applied with ULO at $0.5^{\circ} \mathrm{C}$ was most tolerant: codling moth and diapausing TSM; moderately tolerant: lightbrown apple moth larvae and obscure mealybug; and least tolerant: greedy scale. Griffin et al. (2013) found a similar order of tolerance to ethyl formate + carbon dioxide treatment at ambient temperatures with lightbrown apple moth eggs being very tolerant and mixed species of thrips being among the susceptible species in the presence of apples. Chhagan et al. (2013) also found that New Zealand flower thrips on apricots were susceptible to ethyl formate + carbon dioxide treatment at $15^{\circ} \mathrm{C}$. Over 10 years of research has been conducted in Australia to generate efficacy data for ethyl formate + carbon dioxide against pests of grapes and citrus (De Lima 2009, 2010) where, in general, eggs tended to be the most tolerant life stages of the lepidopteran, spider and mite species tested, while crawlers were the most tolerant of the mealybug species, and adults of the thrips species. The Australian research reported effective ethyl formate + carbon dioxide treatments at $5^{\circ} \mathrm{C}$ in the absence of any fruit for tolerant species (i.e. LBAM and red-backed spider), with values ranging from 44 to $90 \mathrm{~g} / \mathrm{m}^{3}$ ethyl formate for 1-4 h; values for susceptible species (longtailed mealybug, western flower thrips, plague thrips and the summer nondiapausing form of two-spotted mite) ranged from 9 to $38 \mathrm{~g} / \mathrm{m}^{3}$ ethyl formate for $1-4 \mathrm{~h}$.

Codling moth is a difficult pest to control postharvest, because the young larvae are internally located, diapausing larvae are highly tolerant of cool storage, and the eggs are highly tolerant of $\mathrm{MeBr}$ fumigation. The present results showed that diapausing fifth instar larvae, which exit the fruit to cocoon and enter a diapausing state to overwinter, were susceptible to ethyl formate or ethyl acetate. Low temperature ULO estimated $99 \%$ mortality times were reduced from hundreds of days to $<1$ day. However, internally located second/third instar larvae were more difficult to kill due to being protected from exposure to ethyl formate or ethyl acetate ULO treatment in cool storage, requiring ca 6 days of exposure. Other studies have shown that ethyl formate is not effective against internally located fruit fly larvae (C. De Lima, Department of Agriculture and Food, Western Australia, unpublished data).

Diapausing TSM were also very tolerant to cool storage, surviving for an estimated hundreds of days. Exposure to ethyl formate or ethyl acetate reduced the lethal $99 \%$ mortality time to $<1$ day or $<2$ days, respectively. De Lima (2009) reported that TSM eggs tended to be the most tolerant life stage to ethyl formate treatment, compared with adults and larvae, but diapausing adults were not tested in that study.

Although many researchers have tested the efficacy of ethyl formate as a fumigant for pest control, few reports exist for similar studies using ethyl acetate. Research by van Epenhuijsen et al. (2007) reported an estimated 82.7-91.1\% mortality of onion thrips eggs was achieved using $94-120 \mathrm{~g} / \mathrm{m}^{3}$ ethyl acetate.

Postharvest treatment of fresh fruit at cool storage temperatures would maintain the coolchain and benefit fruit quality. Some of the fruit quality issues associated with fumigation may be the result of having to break the coolchain to treat the fruit. According to its label, it is recommended that VAPORMATE ${ }^{\mathrm{TM}}$ (ethyl formate + carbon dioxide) be applied at $>10$ or 


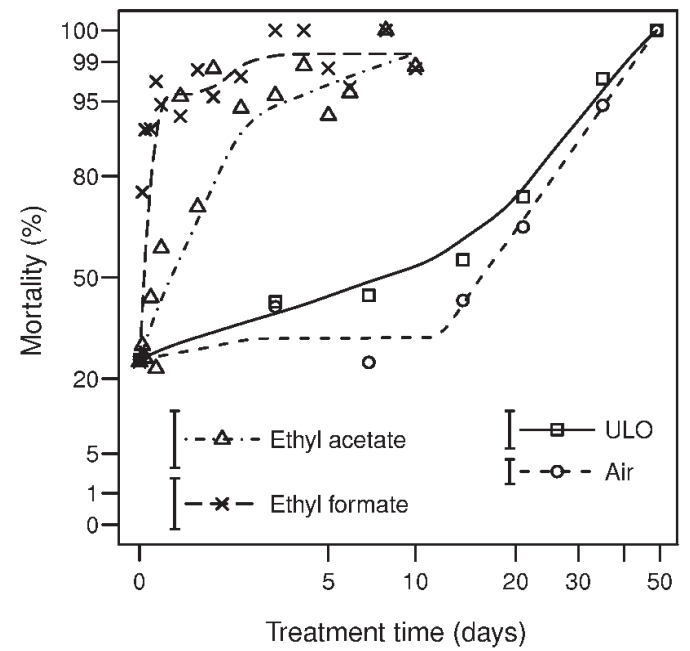

Figure 3 Fitted mortality lines for second/third instar codling moth larvae during ultra low oxygen (ULO), air, or ULO with either ethyl acetate or ethyl formate applied in cool storage at $0.5^{\circ} \mathrm{C}$. The air treatment is included as a control. $\mathrm{n}=51-184$ for each sample point.

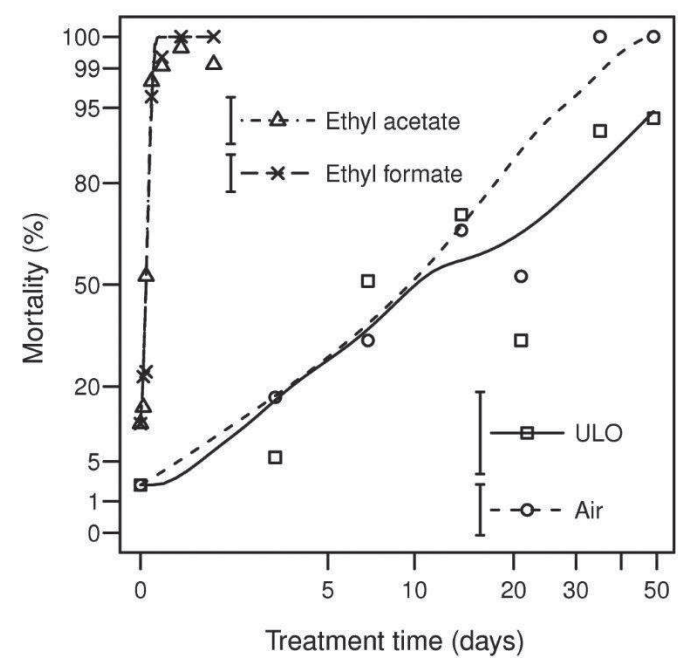

Figure 5 Fitted mortality lines for mixed life stages of obscure mealybug during ultra low oxygen (ULO), air or ULO with either ethyl acetate or ethyl formate applied in cool storage at $0.5^{\circ} \mathrm{C}$. The air treatment is included as a control. $\mathrm{n}=140-8315$ for each sample point.

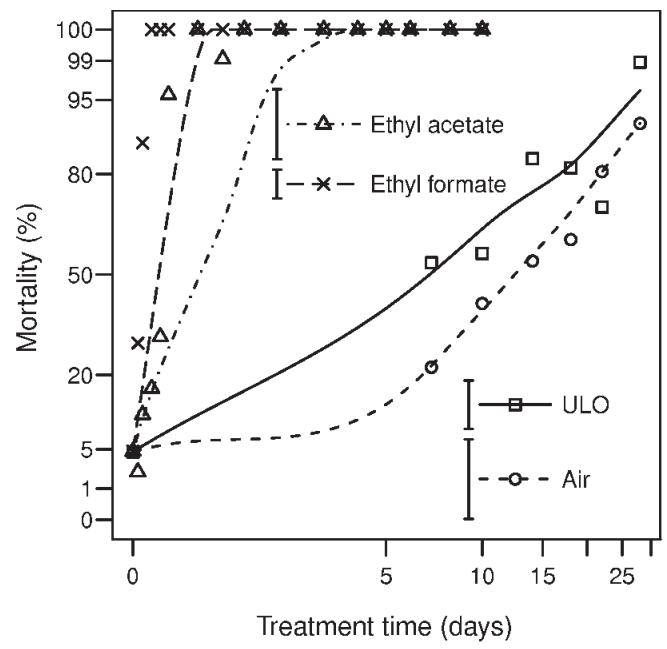

Figure 4 Fitted mortality lines for fifth instar lightbrown apple moth larvae (programmed for diapause) during ultra low oxygen (ULO), air, or ULO with either ethyl acetate or ethyl formate applied in cool storage at $0.5^{\circ} \mathrm{C}$. The air treatment is included as a control. $\mathrm{n}=65-276$ for each sample point.

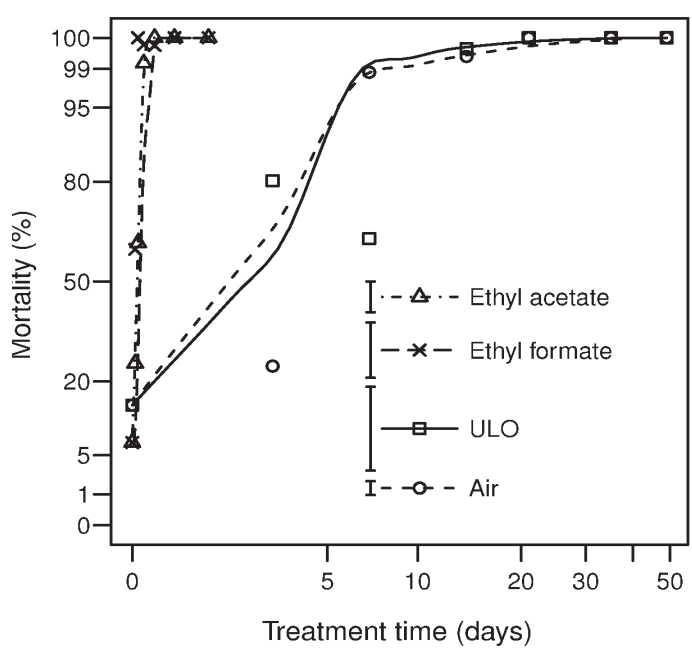

Figure 6 Fitted mortality lines for mixed life stages of greedy scale during ultra low oxygen (ULO), air or ULO with either ethyl acetate or ethyl formate applied in cool storage at $0.5^{\circ} \mathrm{C}$. The air treatment is included as a control. $\mathrm{n}=$ 807-3809 for each sample point. 
$15^{\circ} \mathrm{C}$. Manufacturers claim that this is to ensure that target pests are active (Brian Hamilton, BOC gases personal communication). The present study indicates that there may be potential to apply ethyl formate at lower temperatures, as found in cool storage, to disinfest fresh produce to control a range of pests. Further research is warranted to determine the tolerance of other pest life stages and species to ethyl formate and ethyl acetate with controlled atmosphere or air cool storage, and to examine the subsequent export quality of fresh produce cultivars.

\section{ACKNOWLEDGEMENTS}

We are grateful to Dave Rogers and Boric Orchards for the supply of apples; Anne Barrington and the Plant \& Food Research insect-rearing team for supply of pests; Melissa Griffin for excellent technical assistance; and Pipfruit NZ and the Ministry of Business, Innovation and Employment (C06X0709) for funding this research.

\section{REFERENCES}

Anonymous 1993. Code of federal regulations, food and drugs. Office of the Federal Register National Archives and Records Administration, Washingon DC, USA. Pp. 170-199.

Bradfield GC, Dentener PR, Connolly PG 2002. Using chemical structure to select compounds for insect disinfestation research. New Zealand Plant Protection 55: 430 (Abstract only).

Bradfield G, Dentener P, Connolly P 2003. Effect of temperature on the mortality of Epiphyas postivittana Walker exposed to GRAS compounds. In: Proceedings Australasian Postharvest Horticulture Conference. p. 70.

Brinton FE, Proverbs MD, Cary BE 1969. Artificial diet for mass production of the codling moth, Carpocapsa pomonella (Lepidoptera: Olethreutidae). Canadian Entomology 101: 577-584.

Chambers JM, TJ Hastie 1992. Statistical Models in S. Wadsworth and Brooks/Cole, Pacific Grove, CA, USA.
Chhagan A, Jamieson LE, Griffin MJ, PageWeir NEM, Poulton J, Zulhendri F, Feng R, Connolly PG, Davis VA, Olsson S, Redpath SP, Kean AM, Woolf AB 2013. Postharvest management of New Zealand flower thrips (Thips obscuratus) on apricots using ethyl formate or pyrethrum-based treatments. New Zealand Plant Protection 66: 63-74.

Clare GK, Ochieng-Odero JPR, Dalzell SJ, Singh $\mathrm{P}$ 1987. A practical rearing method for leafroller (Lepidoptera: Tortricidae). New Zealand Journal of Zoology 14: 597-601.

Damcevski KA, Dojchinov G, Woodman JD, Haritos VS 2010. Efficacy of vaporised ethyl formate/ carbon dioxide formulation against storedgrain insects: effect of fumigant concentration, exposure time and two grain temperatures. Pest Management Science 66(4): 432-438.

De Lima CPF 2006. Fumigation of table grapes with ethyl formate against quarantine pests. 2006 Annual International Research Conference on Methyl Bromide Alternatives and Emissions Reductions, Orlando, Florida, USA, 6-9th November, 2006. http://www. mbao.org/2006/06Proceedings/097 DeLimapaperontablegrapefumigation.pdf (accessed 20 May 2013).

De Lima C 2009. Fumigation of table grapes using ethyl formate + carbon dioxide as a quarantine treatment. Department of Agriculture and Food, Western Australia. 53 p.

De Lima C 2010. Fumigation trials of citrus using ethyl formate + carbon dioxide as a quaranitine treatment. Department of Agiculture and Food, Western Australia. 34 p.

Finkelman S, Lendler E, Navarro S, Navarro H, Ashbell G 2010. New prospects for ethyl formate as a fumigant for the date industry. Proceedings of the 10th International Working Conference on Stored Product Protection, Lisboa, Portugal. Pp. 359-364. http://pub.jki.bund.de/index.php/JKA/article/ view/510/1225 (accessed 20 May 2013).

Griffin MJ, Jamieson LE, Chhagan A, PageWeir NEM, Poulton J, Davis V, Zulhendri F, Connolly PG 2013. The potential of ethyl formate + carbon dioxide to control a range of horticultural pests. New Zealand Plant Protection 66: 54-62. 
Hallagan JB, Hall RL 1995. FEMA GRAS A GRAS assessment program for flavor ingredients. Regulatory Toxicology and Pharmacology 21: 422-430.

Krishna H, Van Epenhuijsen CW, Carpenter A, Zhang Z, Brash DW, Ryan R, Bishop S, Grant N, Fontinha M 2002. Ethyl formate: a potential organic fumigant for fresh produce. New Zealand Plant Protection 55: 444 (Abstract only).

Lallu N, Johnston J, Punter M, Billing D, Pidakala P, Haynes G, Farrell M 2009. Potential for DCA (dynamic controlled atmosphere) storage of 'Braeburn' and 'Pink Lady' apples. Plant \& Food Research Client Report No. 27739, Plant \& Food Research, Auckland, New Zealand. 41 p.

Lallu N, Punter M, Billing D, Pidakala P, Haynes G, Johnston J 2010. Optimising carbon dioxide requirements for DCA (dynamic controlled atmosphere) storage of 'Braeburn' and 'Pink Lady' apples. Plant \& Food Research Client Report No: 34711, Plant \& Food Research, Auckland, New Zealand. 40 p.

Lay-Yee M, Whiting DC 1996. Response of 'Hayward' kiwifruit to high-temperature controlled atmosphere treatments for control of two-spotted spider mite (Tetranychus urticae). Postharvest Biology and Technology 7(1/2): 73-81.

Prange RK, DeLong JM, Leyte JC, Harrison PA 2002. Oxygen concentrations affects chlorophyll fluorescence in chlorophyllcontaining fruit. Postharvest Biology and Technology 24: 201-205.

Preisler HK, Robertson JL 1989. Analysis of timedose-mortality data. Journal of Economic Entomology 82: 1534- 1542.

R Development Core Team 2012. R: A language and environment for statistical computing. $\mathrm{R}$ Foundation for Statistical Computing, Vienna, Austria. ISBN 3-900051-07-0, URL http://www.R-project.org/.

Simpson T, Bikoba V, Mitcham EJ 2004. Effects of ethyl formate on fruit quality and target pest mortality for harvested strawberries. Postharvest Biology and Technology 34(3): 313-319.
Simpson T, Bikoba V, Tipping C, Mitcham EJ 2007. Ethyl formate as a postharvest fumigant for selected pests of table grapes. Journal of Economic Entomology 100(4): 1084-1090.

Singh P, Clare GK 1993. A method for continuous production of diapausing twospotted mite in the laboratory. New Zealand Entomologist 16: 94-99.

US FDA 2006. GRAS Substances (SCOGS) Database. http://www.fda.gov/Food/Food IngredientsPackaging/GenerallyRecognized as SafeGRAS/GRASSubstancesSCOGS Database/default htm (accessed 20 April 2013).

US FDA 2011. Everything Added to Food in the United States (EAFUS). http://www.fda.gov/ food/foodingredientspackaging/ucm115326. htm (accessed 20 April 2013).

van Epenhuijsen CW, Hedderley DI, Somerfield KG, Brash DW 2007. Efficacy of ethyl formate and ethyl acetate for the control of onion thrips (Thrips tabaci). Journal of Crop and Horticultural Science 35: 267-274.

Whiting DC, Foster SP, Maindonald JH. 1991. Effect of oxygen, carbon dioxide and temperature on the mortality responses of Epiphyas postvittana (Lepidoptera: Tortricidae). Journal of Economic Entomology 84(5): 1544-1549.

Whiting DC, Foster SP, van den Heuvel J, Maindonald JH 1992. Comparative mortality responses of four Tortricid (Lepidoptera) species to a low oxygencontrolled atmosphere. Journal of Economic Entomology 85(6): 2305-2309.

Whiting DC, O'Connor GM, van den Heuvel J, Maindonald JH 1995. Comparative mortalities of six Tortricid (Lepidoptera) species to two high-temperature controlled atmospheres and air. Journal of Economic Entomology 88(5): 1365-1370.

Whiting DC, Hoy LE 1997. High-temperature controlled atmospheres and air to control obscure mealybug (Hemiptera: Pseudococcidae) on apples. Journal of Economic Entomology 90(2): 546-550. 